
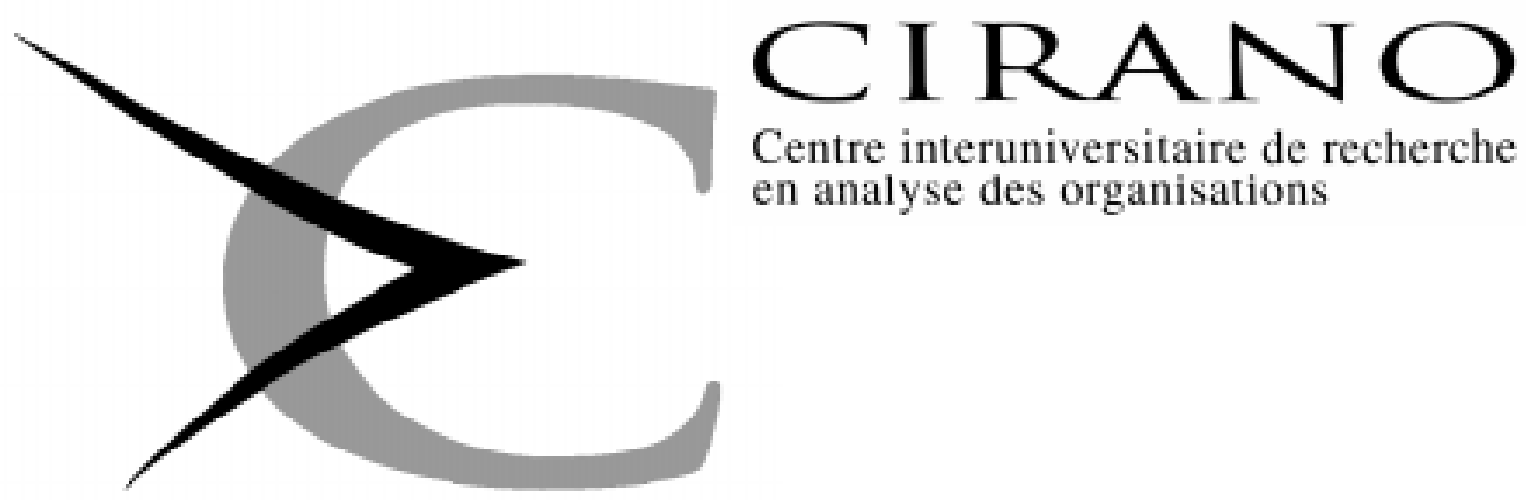

Centre interuniversitaire de recherche en analyse des organisations

Série Scientifique

Scientific Series

97s-38

\title{
How Do Young People \\ Choose College Majors?
}

Claude Montmarquette, Kathy

Cannings, Sophie Mahseredjian

Montréal

Novembre 1997 


\section{CIRANO}

Le CIRANO est une corporation privée à but non lucratif constituée en vertu de la Loi des compagnies du Québec. Le financement de son infrastructure et de ses activités de recherche provient des cotisations de ses organisations-membres, d'une subvention d'infrastructure du ministère de l'Industrie, du Commerce, de la Science et de la Technologie, de même que des subventions et mandats obtenus par ses équipes de recherche. La Série Scientifique est la réalisation d'une des missions que s'est données le CIRANO, soit de développer l'analyse scientifique des organisations et des comportements stratégiques.

CIRANO is a private non-profit organization incorporated under the Québec Companies Act. Its infrastructure and research activities are funded through fees paid by member organizations, an infrastructure grant from the Ministère de l'Industrie, du Commerce, de la Science et de la Technologie, and grants and research mandates obtained by its research teams. The Scientific Series fulfils one of the missions of CIRANO: to develop the scientific analysis of organizations and strategic behaviour.

\section{Les organisations-partenaires / The Partner Organizations}

-École des Hautes Études Commerciales

-École Polytechnique

-McGill University

-Université de Montréal

-Université du Québec à Montréal

-Université Laval

-MEQ

-MICST

-Avenor

-Banque Nationale du Canada

-Bell Québec

-Caisse de dépôt et placement du Québec

-Fédération des caisses populaires Desjardins de Montréal et de l'Ouest-du-Québec -Hydro-Québec

-Raymond, Chabot, Martin, Paré

-Scetauroute

-Société d'électrolyse et de chimie Alcan Ltée

-Téléglobe Canada

-Ville de Montréal

Ce document est publié dans l'intention de rendre accessibles les résultats préliminaires de la recherche effectuée au CIRANO, afin de susciter des échanges et des suggestions. Les idées et les opinions émises sont sous l'unique responsabilité des auteurs, et ne représentent pas nécessairement les positions du CIRANO ou de ses partenaires.

This paper presents preliminary research carried out at CIRANO and aims to encourage discussion and comment. The observations and viewpoints expressed are the sole responsibility of the authors. They do not necessarily represent positions of CIRANO or its partners.

ISSN 1198-8177 


\title{
How Do Young People Choose College Majors?*
}

\author{
Claude Montmarquette $e^{\dagger}$, Kathy Cannings ${ }^{*}$, \\ Sophie Mahseredjian
}

\begin{abstract}
Résumé / Abstract
Les études antérieures sur les déterminants du choix d'une filière universitaire ont présumé une probabilité constante de succès entre les différentes filières d'études ou des revenus constants entre les filières. Notre modèle dépasse ces deux hypothèses restrictives en construisant une variable de revenus anticipés pour expliquer la probabilité qu'un étudiant choisisse une filière parmi quatre domaines de spécialisation. La construction d'une variable de revenus anticipés exige de l'information sur la probabilité de succès perçue par l'étudiant, sur les revenus estimés des diplômés dans toutes les spécialisations et sur les revenus alternatifs de l'étudiant s'il échoue à l'obtention de son diplôme. En utilisant des données du National Longitudinal Survey of Youth, nous évaluons les chances de succès dans toutes les filières d'études pour tous les individus de l'échantillon. D'autre part, les revenus individuels estimés des diplômés dans toutes les filières sont obtenus en utilisant les coefficients des régressions de Rumberger et Thomas (1993) obtenus de l'enquête Survey of Recent College Graduates de 1987. Puis nous calculons des revenus alternatifs idiosyncratiques avec une condition dérivée de notre modèle de choix de filière universitaire appliqué à notre échantillon d'étudiants. Finalement, avec un modèle de logit polytomique mixte, nous expliquons le choix individuel d'un domaine d'études. Les résultats de ce travail montrent que la variable de revenus anticipés idiosyncratique est essentielle dans le choix d'un domaine d'études. Toutefois, il y a des différences significatives dans l'impact des revenus anticipés par sexe et par race.
\end{abstract}

\footnotetext{
${ }^{*}$ Corresponding Author: Claude Montmarquette, CIRANO, 2020 University St., $25^{\text {th }}$ fl., Montréal, Qc, Canada H3A 2A5 Tel: (514) 985-4015 Fax: (514) 985-4039 e-mail: montmarc@ cirano.umontreal.ca We thank Christian Gouriéroux, Louis Lévy-Garboua and John J. Siegfried for their suggestions on an earlier version of this paper. We received helpful comments from seminar participants at the Université Laval, the World Bank, the Université de Paris-I (Panthéon-Sorbonne) and the Université d'Orléans. The financial support of the Social Sciences and Humanities Research Council of Canada is gratefully acknowledged. The usual disclaimer applies.

${ }^{\dagger}$ Université de Montréal, CRDE and CIRANO

‡ University of Uppsala

$\S$ Université de Montréal and CRDE
} 
Previous studies on the determinants of the choice of college major have assumed a constant probability of success across majors or a constant earnings stream across majors. Our model disregards these two restrictive assumptions in computing an expected earnings variable to explain the probability that a student will choose a specific major among four choices of concentrations. The construction of an expected earnings variable requires information on the student's perceived probability of success, the predicted earnings of graduates in all majors and the student's expected earnings if he (she) fails to complete a college program. Using data from the National Longitudinal Survey of Youth, we evaluate the chances of success in all majors for all the individuals in the sample. Second, the individuals' predicted earnings of graduates in all majors are obtained using Rumberger and Thomas's (1993) regression estimates from a 1987 Survey of Recent College Graduates. Third, we obtain idiosyncratic estimates of earnings alternative of not attending college or by dropping out with a condition derived from our college major decision-making model applied to our sample of college students. Finally, with a mixed multinominal logit model, we explain the individuals choice of a major. The results of the paper show that the expected earnings variable is essential in the choice of a college major. There are, however, significant differences in the impact of expected earnings by gender and race.

Mots Clés : $\quad$ Choix de filières, revenus anticipés idiosyncratiques, modèle polytomique mixte

Keywords: College majors, expected idiosyncratic earnings, mixed multinominal logit model

JEL : J24, C35 


\section{INTRODUCTION}

At some point during the early stages of an undergraduate education, every college student must choose an area of concentration such as science, business, liberal arts or education. A certain proportion of these undergraduates will not finish college, and an ill-advised choice of concentration may be a contributing factor. It is generally thought, for example, that majoring in science is more difficult, and hence riskier, than majoring in education. It may be, however, that people who differ in their socioeconomic and ascriptive characteristics as well as cognitive capabilities also differ in their willingness to choose riskier areas of concentration. If it is true, for example, that students from more affluent socioeconomic backgrounds are more willing to take risks in the pursuit of their education, then, in effect, more privileged socioeconomic backgrounds enhance the educational choices of those who possess them. Similarly, insofar as men are willing to take more risks than women in the choice of concentration, there is an element of gender inequality in educational choice.

In focusing on how do young people choose majors, our approach differs from other studies that have analyzed the role of uncertainty on the demand for education and the choice of occupations. For example, Kodde (1986) found that increases in uncertainty concerning future incomes increased the demand for higher education. Orazem and Mattila (1986), using annual data on the entry-level occupational choices of Maryland High School graduates from 1951 through 1969, show that the probability that an occupation is chosen varies directly with the mean return to human capital such that occupation is inversely related to the variance of returns within the occupation. In addition, a number of studies have shown that gender influences both the demand for education and occupational choice, given the differences between men and women in their perceptions of the employment opportunities open to them and their planned patterns of labor force participation [Polachek (1981); Blakemore and Low (1984); Zalokar (1988); Blau and Ferber (1991)].

While these studies have explored the impacts of socioeconomic background and ascriptive characteristics such as gender on the demand for education and the choice of occupation, they have not addressed the more specific question of the impacts of these variables on the choice of undergraduate concentration. There are, however, important exceptions. Berger (1988a) shows that, in their choice of concentrations, individuals are less influenced by initial earnings levels in occupations related to different concentrations and more influenced by the stream of earnings that these occupations are expected to yield. In analyzing the relation 
between the choice of college major and earnings, Berger makes the implicit assumption that different occupations with different earnings streams are tightly linked to different college concentrations. This assumption can, of course, be overdrawn in a liberal arts educational environment such as exists in the United States where professional specialization in the educational system typically takes place in advanced degree programs. Nevertheless, even in such an educational setting, it can be argued that students perceive certain college majors as leading to subsequent training that provides access to occupations that offer higher pay and more employment security. For example, if one wants to enter medicine - an occupation that tends to offer higher pay and more employment security - one must successfully complete a science degree.

Yet, if the choice of a science major presents a greater probability of noncompletion, then an individual who is motivated by future earnings prospects may choose a major that offers a greater probability of successful completion combined with a smaller subsequent earnings stream. If, in fact, the choice of college major significantly determines subsequent career progress, then, for the sake of both the efficient allocation of human resources and the elimination of discriminatory barriers, it is important to know why certain types of individuals choose certain types of college majors. Assuming that 1) the choice of college major is a significant determinant of subsequent career success, 2) riskier majors are associated with higher subsequent earnings streams, and 3) students are motivated in their choice of major by the possibilities of accessing higher earnings streams, an analysis of the impact of the perceived probability of success in a college major on the choice of college major can have important policy implications. Duru and Mingat (1979) were the first to present a model that takes into account the probability of success in selecting a major. They suggest a trade off between the economic return to education and the risk of failure. Paglin and Rufolo (1990, p. 125) have also made a major contribution in this direction by showing that "comparative advantage influences the observed choice of college major and that quantitative ability is one of the most important factors in this choice". Solnick (1995) showed that women who begin in traditionally female majors are more likely to shift to other majors if they attend a single-sex woman's college. However, Canes and Rosen (1995) have rejected the 'role model' hypothesis (following in her footsteps) for women's choice of college majors. Fiorito and Dauffenbach (1982) and Easterlin (1995) have insisted on the nonprice (preferences) determinants of the choice of undergraduate major. Finally, Altonji (1993) has proposed an extensive theoretical model dealing with most of these issues. In his model, education is considered as a series of sequential 
decisions about whether to attend college, in what field to major, and whether to drop out, based on uncertainly related economic returns, personal tastes and abilities. His work is a part of a research agenda that supports ours.

This paper analyzes the extent to which the choice of college major depends on the student's expected earnings in that major as opposed to other areas of concentration that could have been chosen. Previous studies on the determinants of the choice of college major have assumed a constant probability of success across majors or a constant earnings stream across majors [see Cannings, Montmarquette and Mahseredjian (1994) for the latter assumption]. Our model disregards these two restrictive assumptions. Choosing a major is a decision made under uncertainty as one must successfully complete the major to gain the associated earnings. We test the hypothesis that abilities influence the perceived probability of success in a major and we explore the role of family background and family culture on the determinants of college major. We also use the model to determine whether distinct groups exhibit significant differences in their choice of college major. In the next section of the paper, we develop a model of a decision-making process in which the student's expected earnings in a major is the central determinant of the choice of a major. We also discuss some econometric issues associated with the model. In Section 3, we present the data. In Section 4, we discuss the empirical results of the students' perceived probability of success. Section 5 discusses the estimates of earnings of graduates in all majors and the students' earnings alternative if they fail to complete a college program. In Section 6, we present the empirical results on the choice of majors. Section 7 concludes.

\section{THEORETICAL FRAMEWORK AND ECONOMETRIC ISSUES}

Define $\mathrm{p}_{\mathrm{ij}}$ as the perceived probability of success of individual $\mathrm{i}$ in major $\mathrm{j}$ and $\mathrm{e}_{\mathrm{ij}}$ the earnings individual $\mathrm{i}$ expects by graduating in major $\mathrm{j}$.

For given preferences, assume that the expected utility of individual i choosing major $\mathrm{j}$ depends on expected earnings :

$$
\begin{aligned}
E\left(u_{i j}\right)=p_{i j}(x) e_{i j}(z)+\left(1-p_{i j}(x)\right) e_{i o}(z), & i=1, \ldots, N, \\
& j=1, \ldots, m,
\end{aligned}
$$


where $\mathrm{x}$ and $\mathrm{z}$ are factors that influence the probability of success and earnings of graduates respectively. $e_{i o}$ is the earnings alternative with no success in any major. A complete model would consider the probability of graduates finding employment in the specific majors ${ }^{1}$. Here, we assume that expected earnings of graduates are always realized. Then, an individual $i$ will choose $j$ over the alternative $\mathrm{k}$ if,

$$
\mathrm{E}\left(\mathrm{u}_{\mathrm{ij}}\right) \geq \mathrm{E}\left(\mathrm{u}_{\mathrm{ik}}\right)
$$

that is,

$$
\mathrm{p}_{\mathrm{ij}}(\mathrm{x})\left(\mathrm{e}_{\mathrm{ij}}(\mathrm{z})-\mathrm{e}_{\mathrm{ik}}(\mathrm{z})\right)+\left(\mathrm{p}_{\mathrm{ij}}(\mathrm{x})-\mathrm{p}_{\mathrm{ik}}(\mathrm{x})\right)\left(\mathrm{e}_{\mathrm{ik}}(\mathrm{z})-\mathrm{e}_{\mathrm{io}}(\mathrm{z})\right) \geq 0 .
$$

If $\mathrm{p}_{\mathrm{ij}}$ substantially differs from $\mathrm{p}_{\mathrm{ik}}$, it could play a major role in choosing major $\mathrm{j}$ with respect to smaller differences in $\left(\mathrm{e}_{\mathrm{ij}}-\mathrm{e}_{\mathrm{ik}}\right)$. With $\mathrm{p}_{\mathrm{ij}} \sim \mathrm{p}_{\mathrm{ik}}$, the main determinant of choosing a major is the earnings difference in occupations expected from the two majors. For very talented students, the probability of success is high in all majors and earnings at graduation should matter more than the probabilities of success.

Preceding the choice of college major is the decision to go to college. For at least one major, the discounted expected earnings of $\mathrm{s}$ years of additional schooling is equal to or greater than the discounted earning alternative, the tuition and information costs :

$$
\begin{gathered}
\int_{s}^{\mathrm{n}+\mathrm{s}}\left[\mathrm{p}_{\mathrm{ij}}(\mathrm{x}) \mathrm{e}_{\mathrm{ij}}(\mathrm{z})+\left(1-\mathrm{p}_{\mathrm{ij}}(\mathrm{x})\right) \mathrm{e}_{\mathrm{io}}(\mathrm{z})\right] \exp (-\mathrm{rt}) \mathrm{dt} \\
\geq \int_{0}^{\mathrm{n}} \mathrm{e}_{\mathrm{io}}(\mathrm{z}) \exp (-\mathrm{rt}) \mathrm{dt}+\int_{0}^{\mathrm{s}} \mathrm{sc}_{\mathrm{ij}} \exp (-\mathrm{rt}) \mathrm{dt},
\end{gathered}
$$

\footnotetext{
${ }^{1}$ Betts and McFarland (1995) showed that total community college enrollments respond to changing labor market conditions.
} 
where $\mathrm{n}$ is the expected number of years in the labor force, and $\mathrm{r}$ the student's discount rate. The schooling costs $\mathrm{sc}_{\mathrm{ij}}$ include tuition and information costs. Solving for the integrals, equation (3) implies :

$\mathrm{p}_{\mathrm{ij}}(\mathrm{x}) \geq \frac{\exp (\mathrm{rs})-1}{\mathrm{e}_{\mathrm{ij}}(\mathrm{z})-\mathrm{e}_{\mathrm{io}}(\mathrm{z})}\left[\mathrm{e}_{\mathrm{io}}(\mathrm{z})+\mathrm{sc}_{\mathrm{ij}} /(1-\exp (-\mathrm{rn}))\right]=\tilde{\mathrm{p}}_{\mathrm{ij}}$

With our sample of students, this equation will be useful in the empirical specification of the model, which is discussed next.

Define $\mathrm{u}_{\mathrm{ij}}^{*}$ as the expected level of indirect utility for individual $\mathrm{i}$ in major $\mathrm{j}$, expressed as a linear function of the individual's expected earnings $\mathrm{y}^{*}$, normalized by the characteristics of the individual (w), and an unobserved random component $(\varepsilon)$ that reflects the idiosyncrasies of this individual's preferences for major $\mathrm{j}^{2,3}$ :

$$
\mathrm{u}_{\mathrm{ij}}^{*}=\beta^{\prime} \mathrm{y}_{\mathrm{ij}}^{*}+\alpha_{\mathrm{j}}^{\prime} \mathrm{w}_{\mathrm{i}}+\varepsilon_{\mathrm{ij}}
$$

where

$$
y_{i j}^{*}=p_{i j}(x) e_{i j}(z)+\left(1-p_{i j}(x)\right) e_{i o}(z)
$$

\footnotetext{
${ }^{2}$ There are no specific attitude questions or indicators of preferences for college students in the NLSY data set used in this paper.

${ }^{3}$ The linearity of equation (5) suggests that the assumption of neutrality with respect to risk should be retained. Extensions on this question along the lines proposed by Orazem and Mattila (1986) would be worth considering in future work.
} 
$\mathrm{u}_{\mathrm{ij}}^{*}$ is unobserved. However, the choice $\mathrm{C}_{\mathrm{ij}}$ made by the individual is observed :

$$
\begin{aligned}
& C_{i j}=1, \text { if } u_{i j}^{*} \geq u_{i k}^{*} \text { for all } k \neq j, \\
& C_{i j}=0 \text {, otherwise. }
\end{aligned}
$$

From McFadden's (1973) random utility models and, if the residuals $\varepsilon$ are independently and identically distributed with the Type 1 extreme-value (or Gumbell) distribution, we can derive a mixed model of the discrete choice [see Maddala (1983), and Hoffman and Duncan (1988)] of the probability $\mathrm{P}_{\mathrm{ij}}$, for individual $\mathrm{i}$ choosing major $\mathrm{j}$ :

$$
\mathrm{P}_{\mathrm{ij}}=\operatorname{Prob}\left(\mathrm{C}_{\mathrm{ij}}=1\right)=\frac{\exp \left(\beta^{\prime} \mathrm{y}_{\mathrm{ij}}^{*}+\alpha_{\mathrm{j}}^{\prime} \mathrm{w}_{\mathrm{i}}\right)}{\sum_{\mathrm{k}=1}^{\mathrm{m}} \exp \left(\beta^{\prime} \mathrm{y}_{\mathrm{ik}}^{*}+\alpha_{\mathrm{k}}^{\prime} \mathrm{w}_{\mathrm{i}}\right)},
$$

where $\mathrm{w}_{\mathrm{i}}$ is the vector of individual characteristics for individual $\mathrm{i}$ (age, gender, socioeconomic background, etc.). The coefficients $\alpha$ differ for each concentration. We also assume a different constant term for each concentration. Given a new individual with specified characteristics, we can predict the probability that the individual will choose one of the m possible concentrations. $y_{i j}^{*}$ is the expected earnings when enrolling in the concentration $j$ for the individual $i$. The impact of the explanatory variables $y_{\mathrm{ij}}^{*}$ is assumed to be constant across alternatives. Therefore, the coefficient $\beta$ is the same for each concentration with an expected positive sign : an individual chooses the concentration that, given his or her preferences, has the highest expected earnings. An earlier discussion suggests, however, different values for $\beta$ according to gender and socioeconomic status of the individuals might be appropriate. Stratified samples will be considered in the empirical estimation of the model. 
Previous studies on the determinants of the choice of college major have assumed a constant probability of success across majors. From equation (2), this simplification identifies the different earnings stream across majors as the principal determinant of the choice of major. Equation (2) also indicates that by assuming a constant earnings stream across majors the difference in the probabilities of success across majors becomes the principal component for an individual to choose a concentration. Our model disregards these two restrictive assumptions. We will discuss, in section 4 , the effects associated with these restrictive assumptions in explaining the probability that an individual will choose a specific major among $\mathrm{m}$ concentrations.

However, we cannot directly estimate equation (6), since the components of the expected earnings variable for each concentration, $\mathrm{y}_{\mathrm{ij}}{ }^{*}$, are not observable. The students' perceived probability of success, $\mathrm{p}_{\mathrm{ij}}^{*}$, the expected earnings after graduation, $\mathrm{e}_{\mathrm{ij}}^{*}$, and the earnings alternative, $\mathrm{e}_{\mathrm{i} 0}^{*}$, are ex-ante variables that must be inferred by the econometrician for all the different college majors that students consider.

The decision-making process is that the individuals evaluate their chances of success in all majors based on their differential probabilities of success. Assume that the underlying probability of success is defined by the regression :

$$
\begin{array}{ll}
\mathrm{p}_{\mathrm{ij}}^{*}=\gamma_{\mathrm{j}}^{\prime} \mathrm{x}_{\mathrm{ij}}+\mu_{\mathrm{ij}}, \quad \mathrm{i}=1, \ldots, \mathrm{N}, \\
\mathrm{j}=1, \ldots, \mathrm{m} .
\end{array}
$$

We must know the vector of parameters $\gamma_{j}$ from a set of independent variables $x$, for example some ability and informational background variables, to infer for each student in our sample his (her) perceived probability of success in all majors. $\mu_{\mathrm{ij}}$ is an error term. The latent variable $\mathrm{p}_{\mathrm{ij}}^{*}$ is unobservable, but we observe a dummy variable $\mathrm{D}$ defined by

$$
\begin{aligned}
& D_{i j}=1, \quad \text { if the individual } i \text { has completed the degree in major } j \\
& D_{i j}=0, \quad \text { otherwise. }
\end{aligned}
$$


In the decision-making process, earnings of graduates also influence students' choices of major. Assume that the earnings of graduates are defined by the regression :

$$
\begin{aligned}
e_{i j}=\lambda_{j} z_{i j}+\xi_{i j}, & i=1, \ldots, N, \\
j & =1, \ldots, m,
\end{aligned}
$$

where $\mathrm{z}$ is a vector of the demographic, ability, family background and college education variables and $\xi$ is an error term. Again, the parameters of the vector $\lambda_{j}$ must be known to infer for each student in the sample his (her) expected earnings after graduation from a major.

Finally, to complete our estimates of the expected earnings for all the individuals in our sample, we need idiosyncratic estimates of earnings alternative. Let us solve equation (4) for $\mathrm{e}_{\mathrm{io}}$ :

$$
\mathrm{e}_{\mathrm{io}} \leq \frac{\mathrm{p}_{\mathrm{i} .} \mathrm{e}_{\mathrm{i} .}-\mathrm{sc}_{\mathrm{i} .}[(\exp (\mathrm{rs})-1) /(1-\exp (-\mathrm{rn}))]}{\mathrm{p}_{\mathrm{i} .}+\exp (\mathrm{rs})-1} .
$$

Given the average perceived probability of success, $\mathrm{p}_{\mathrm{i}}$, and average (expected) earnings $e_{i}$ after graduation, equation (9) indicates the value of the earnings alternative for an individual i not to enroll in a college program ${ }^{4}$. These estimates of earnings alternative are idiosyncratic and preferable to an average earnings of high school graduates

Assuming one can write the likelihood function for the equation system (6) - (9), its estimation will remain a difficult problem. A two-step procedure will be

\footnotetext{
4 This upper bound value for $\mathrm{e}_{\mathrm{i} 0}$ based on average (expected) earnings of college students approximates a situation where a person enters a program with the alternative of dropping out but also to a certain extent of changing fields.
} 
preferred and considering the recursive nature of the system and assuming weak exogeneity for $\mathrm{p}_{\mathrm{ij}}^{*}$ and $\mathrm{e}_{\mathrm{ij}}$, this will provide consistent estimates. ${ }^{5}$

First, assuming the normality of the errors $\mu_{\mathrm{ij}}$, we use a simple probit model with mostly ability variables to estimate the individuals' probabilities of success in each major. From the parameter estimates of equation (7), we then predict the probability of success in each major for all individuals in the sample. Second, we obtain the individuals' predicted earnings in all majors using Rumberger and Thomas's (1993) econometric regression estimates from a 1987 Survey of Recent College Graduates. Third, idiosyncratic earnings alternative $\mathrm{e}_{\mathrm{io}}$ is derived from the first and second computations. ${ }^{6}$ Finally, assuming that residuals $\varepsilon_{\mathrm{ij}}$ are independently and identically distributed with the Type 1 extreme-value distribution (or Gumbell), equation (6) is estimated.

\section{THE DATA}

To estimate the model, we use a subsample drawn from the NLSY cross-sectional sample of 6,111 people, ranging from the ages of 14 and 22 in 1979. ${ }^{7}$ This subsample includes 851 people whose enrollment status on the first of May 1979 was "in college", studying in either business, liberal arts, science or education (see Table 1 for the construction of these concentrations). Unfortunately, the NLSY did not collect what type of degree had been received from 1985 to 1987, thus limiting our ability to increase the sample size. For the students who were enrolled in 1979, the year of graduation was settled to be in 1983 (i.e., five years later). For the others, the graduation years considered were 1981, 1980 and 1979, respectively. ${ }^{8}$ With the elimination of the missing data, the basic sample size for this study is 562 . Of these 562 individuals, 150 were in business, with 68 (45 percent) completing their degree; 189 were in liberal arts, with

\footnotetext{
${ }^{5}$ Weak exogeneity assumes the independence of the error terms $\varepsilon_{\mathrm{ij}}$, $\mu_{\mathrm{ij}}$ and $\xi_{\mathrm{j}}$. See Engle, Hendry and Richard (1983).

6 Following Manski (1993), we assume homogeneity in the way in which students form their expectations. We also assume that rational and conditional expectations are the correct formation of youth expectations about success and earnings for the different majors.

7 In fact, there were three independent probability samples, designed to represent the entire population of youth born in the United States between 1957 and 1964, that were drawn from the NLSY. We used the cross-sectional sample of 6,111 people designed to represent noninstitutionalized civilian American youngsters aged 14-22 in 1979.

${ }^{8}$ Note that the results based on four years before graduation instead of five were similar to those reported in the paper. They are available upon request.
} 
87 (46 percent) completing their degree; 157 were in science, with 80 (51 percent) completing their degree and 66 were in education, with 38 (58 percent) completing their degree. The NLSY data base is supplemented by data on various measures of knowledge and skill gathered by means of the Armed Services Vocational Aptitude Battery (ASVAB) that was administered to NLSY respondents in 1980 to generate the Profile of American Youth study mentioned earlier. ${ }^{9}$

[Insert Table 1 about here]

In Table 2, we have divided the variables measuring individual characteristics into four categories : personal, socioeconomic, educational and regional. The personal variables measure gender, race and the ASVAB test scores. The gender variable, for example, seeks to determine whether women are (as is generally believed) less likely than men to choose science. The ASVAB variables seek to determine whether different types of cognitive capabilities affect the probability of success and expected earnings of graduates in the different concentrations. The socioeconomic variables measure family income, the education and occupational levels of parents, as well as elements of family structure such as the education of siblings. By including these variables, we want to see whether there is any systematic relation between a family background that is more privileged in terms of parental income, education, role models, and stability as independent variables and the type of college concentration chosen. As already mentioned, it may be argued that a more privileged background would lead a student to be willing to risk entering a more demanding concentration in science. The parental education variables measure potential educational advantages due to family background that a student has that may influence him or her to choose a concentration with a higher risk of failure. The regional variables measure college education received in urban areas or outside the South. Depending on where an individual acquires his or her education might affect his or her ability or willingness to choose a riskier concentration. It also represents different opportunity costs.

${ }^{9}$ For a description of the NLSY data base and the Profile of American Youth Study, see the NLS Handbook published by the Center for Human Resource Research, 1988, and NLSY documentation Attachment 4 : Fields of Study in College, and NLSY Attachment 106 : Profiles. 
[Insert Table 2 about here]

Table 3 provides descriptive statistics on the 562 individuals in the sample, 54 percent of whom are male and 85 percent of whom are white. As one might expect, women are over represented in liberal arts and education, and under represented in science. For all but one category of ASVAB scores, those of men are higher than those of women. Women come from families with somewhat higher incomes than those of men, while a larger proportion of men than women have fathers who are professionals. Most of the remaining socioeconomic characteristics are the same for men and women.

[Insert Table 3 about here]

\section{THE EMPIRICAL RESULTS OF STUDENTS' PERCEIVED PROBABILITY OF SUCCESS}

In the first step of the estimation procedure, under the assumption of the normality of the errors, we use the binary probit model for each major to estimate the determinants of the probability of success in each of the four concentrations. The independent variables are those mainly affecting the perceived probability of success, notably the ability and informational background variables. The ability variables are mainly the ASVAB test scores which are key instruments for the purpose of identification and are excluded from the determinants of the choice of college major equation. These ASVAB test scores are derived from an item response curve psychometric model and are assumed to be independent of the student's race, socioeconomic background and schooling.

The variables with the most significant impact on the probability of success in the business major are the ASVAB mathematics knowledge and vocabulary (word knowledge) scores. In liberal arts, the mathematics knowledge affects the probability of success in this major positively and significantly. The SMSA variable is negative and significant. Living in the South is a significant determinant of the probability of success in education. In addition, as might be expected, the ASVAB vocabulary scores are significant in this major. Also, being a woman positively affects the probability of success in education. In science, no variable appears statistically significant, except for the constant 
term. A plausible explanation is the collinearity between the ability variables more important in science, where we also observe higher mean ASVAB scores with less dispersion in science than for any other majors. When tested by a block of variables, the ability variables are always significant for each major ${ }^{10}$.

From the coefficients of the probit models, we then compute the perceived probability of success (SUCCESS) in each major for each of the 562 individuals in the sample. In Table 4, we present descriptive statistics for males and females on the observed and perceived probabilities of success by choice of major. As already pointed out, the observed probabilities are the actual proportions of those who enter a college major and successfully complete that major. ${ }^{11}$ The highest observed probability of success is in education (0.64) and the lowest is in science (0.36). The perceived (or predicted) probabilities of success are based on the probabilities of success of students with particular abilities, personal and socioeconomic characteristics. We call these probabilities "perceived", because we assume that students with particular characteristics (e.g., women) and abilities recognize that, as a group or individuals, they have a different probability of success in a given major than students with other characteristics and abilities.

[Insert Table 4 and 5 about here]

Table 4 shows that our model predicts that 52 percent (the observed probability of success is 0.52 ) of males who entered the business major succeed. If those same students who entered the business major had instead gone into liberal arts, 45 percent of them would have succeeded. Note that this percentage is greater than the observed success rate in liberal arts ( 42 percent). In contrast, if the male business majors had gone into science, only 44 percent would have succeeded, a figure that is less than the 57 percent who actually succeeded.

\footnotetext{
${ }^{10}$ The complete statistical results are not reported, but are available upon request.

${ }^{11}$ In computing the perceived probability of success for all majors, we have considered a student to be successful in a four-year program if he or she graduates within five years. Although it is possible that some students took longer than five years to complete their degree. However, at the time the student decides which major to choose, it is reasonable to assume that the student considers completing the program within the five-year time period. See also footnote 8 .
} 
The probit model predicts that for those who entered liberal arts and education, the perceived probability of success in science is well below the observed probability of success. As for those who entered science, they would do very well in business and education. Table 4 also shows that the male students who actually enter education are especially suited to that major and poorly suited to other majors.

For the female students of any major, the perceived probability of success in education dominates all other probabilities by an important margin. The results of the probit model indicate that most female students, other than science majors, would have done poorly in science had they chosen that major. Women majoring in science show a better or equal predicted probability of success than the male and female observed probabilities of success in business, liberal arts and education majors. At the other spectrum, female education majors would have done poorly in business and science.

\section{ESTIMATES OF EARNINGS OF GRADUATES IN EACH MAJOR AND THE STUDENTS' EARNINGS ALTERNATIVE}

In our theoretical model, the student's expected earnings is a weighted average of earnings when graduating in major $\mathrm{j}, \mathrm{e}_{\mathrm{ij}}$, and earnings alternative, $\mathrm{e}_{\mathrm{i}}$, if the individual has no success in any major. Berger (1988a) showed that the predicted future earnings stream significantly affects the probability of choosing one major over others, more than the predicted beginning earnings. Rumberger (1984) and others have shown that college graduates who major in engineering and business tend to have higher salaries than graduates from other majors and that these differences tend to increase over time (see also Berger, 1988a, 1988b). Data from the NLSY database are not suitable to provide an estimate of a future earnings stream by majors. It is also difficult to find instrumental variables that are not used in the probability of success equations or in the final determinants of the choice of major. To circumvent these difficulties, we have borrowed regression coefficient estimates from the study of Rumberger and Thomas (1993) on the economic returns to college majors. With the 1987 Survey of Recent College Graduates (SRCG), this study provided separate regression coefficients of the

demographic, ability, family background and other determinants of earnings for men and women that graduated in a specific major. We were able to link most 
of these determinants to our set of variables in the NLSY database ${ }^{12}$ to compute the (expected) earnings of graduates in each major for the same 562 individuals in the sample for whom a probability of success was estimated in the previous section. The regression constants were adjusted for the unaccountable variables between the two surveys with the mean annual earnings of employed 1985-86 bachelor degree recipients available, by gender, in Rumberger and Thomas.

Table 5 reports the means of the predicted earnings of graduates by major for the men and women in our sample. In every major, the table shows that the earnings of women are noticeably lower than those for men. We observe that science offers the highest earnings for both men and women, closely followed by business. The education major presents the lowest earnings for graduates. The average graduate male and female in science expect earnings better or equal than all the other average graduates in all fields. The average male and female student entering education face the lowest earnings after graduation across all majors. On average the business and the liberal arts majors expect marginally lower earnings from graduating in education and marginally higher earnings in science ${ }^{13}$.

Comparing the results of Table 4 and Table 5, we note that the projected success in education is higher for an average female student in all fields, but the projected earnings of graduates in education are lower. Therefore, not every woman will choose to major in education. Relative differences in average earnings and in average perceived probabilities of success are observable across all majors in support of the expected earning variable as a major determinant to explain the choice of a major. For a majority of students in science, as for any student likely to succeed in any field, the differentials among earnings of graduates and the students' preferences should play a strong role in their choice.

\footnotetext{
${ }^{12}$ We have considered the following set of overlapping variables between the NLSY and the SRCG databases: demographic (HISPANIC, BLACK, WHITE); family background (MOMEDU, DADEDU, MOMPROF, DADPROF, MOMMAN, DADMAN); college majors (business, liberal arts, science and engineering and education); PUBLIC12 was used as a proxy for the "Private College" variable on the assumption that an individual who has attended grades one to twelve in a public school is likely to continue in a public college; the mean of ASVABSC1, ASVABSC2, ASVABSC3, ASVABSC4, ASVABSC8, recoded to a 0-4 scale was used as a proxy for the "Grade Point Average" variable not available in the NLSY database.

${ }^{13}$ Betts (1996) using evidence from a survey of undegraduates found strong support of the human capital theory assumption that individuals acquire information about earnings by level of education to choose their optimal level of education. He also found that students differ significantly in their beliefs about different fields which implies that students form expectations in various fields. His survey concerned, however, estimates of average salaries not the students own salaries.
} 
We do not account for the future earnings stream as in Berger's (1988a) study for men. Estimating the future earnings stream for women will always remain a difficult problem given the many career interruptions of women for pregnancy and motherhood considerations. We have assumed a different constant term for each concentration in the determinants for major choices (equation 6) to reflect, in part, the different expected permanent earnings.

To complete the specification of the expected earnings variable for each individual $i$ in our sample of college students, we need an idiosyncratic estimate of earnings alternative, $\mathrm{e}_{\mathrm{i},}$, Ignoring the schooling costs, $\mathrm{sc}_{\mathrm{ij}}$, equation (9) simplifies to :

$$
\hat{\mathrm{e}}_{\mathrm{io}} \leq \frac{\hat{\mathrm{p}}_{\mathrm{i} .} \hat{\mathrm{e}}_{\mathrm{i} .}}{\hat{\mathrm{p}}_{\mathrm{i} .}+\exp (\mathrm{rs})-1}
$$

$\hat{\mathrm{p}}_{\mathrm{i} .}$ and $\hat{\mathrm{e}}_{\mathrm{i} .}$ are respectively the average predicted probability of success in college and average (expected) graduate earnings of individual i. With these values, four years of schooling, $\mathrm{s}=5$, and assuming a student's discount rate $\mathrm{r}$ of $3 \%,{ }^{14} \mathrm{we}$ obtain from equation (10) an average earnings alternative of $\$ 13,129$ $\left(\mathrm{e}_{\mathrm{o}_{\mathrm{o}}}=\$ 13,129\right)$ representing $71 \%$ of the average earnings of graduates $(\mathrm{e} . .=\$ 18,437)$. For the male sample, the average earnings alternative is $\$ 13,757$ or $70 \%$ of the average earnings of the male graduates which is $\$ 19,680$. The average female earnings alternative is $\$ 11,853$ or $70 \%$ of the $\$ 16,973$ average earnings of the female graduates.

These differences in earnings expressed in terms of high school graduates are comparable to those reported by Rupert et al. (1996) who found that, over the past 20 years, college graduates earn on average about 52\% more than high school graduates. Finally, our earnings alternative estimates result from a decision process by which an individual decides to attend college, conditional on the parameters of that decision process. As pointed out earlier, we consider this approach an interesting way to integrate into the decision model the sample selectivity issue of dealing with a sample of college students.

${ }^{14}$ This follows Rogers (1994) who suggested an evolutionary rate of time preference of $2 \%$ per year per generation with the young adults discounting the future more rapidly than the elders. 


\section{THE EMPIRICAL RESULTS ON THE CHOICE OF CONCENTRATIONS}

Table 6 reports the results of the mixed model estimated for all 562 individuals in the sample.

[Insert Table 6 about here]

The significance of the $\alpha$ coefficient estimates of the mixed model in Table 6 must be interpreted with respect to major number 4, education. For example, GENDER is highly significant and positive when major number 3 , science, is compared with major number 4 , education. Therefore, a man is significantly more likely to choose science rather than education. Other variables are also statistically significant. The variable NUMSIBLS, the number of siblings currently attending or enrolled in school, and SIBLOEDU, the oldest sibling having completed a college grade are positive and significant in both science and business. In those sectors, prior information and family experience with college play a role in the student's choice of major. FAMILY14 is negative and SMSA is positive and significant in liberal arts which imply that students with two parents at home at age 14, are less likely to choose liberal arts than education and those living in SMSAs are more likely to choose liberal arts than education. If a student is supported by an educational loan, EDULOAN, he or she is less likely to choose business and science than education or liberal arts. This result suggests that students from less affluent family favor less risky concentrations, as intimated by the Duru-Mingat model. Although there are a relatively small number of statistically significant variables, when tested blockwise, the group of personal and regional characteristics, socioeconomic and school factors are all statistically significant. ${ }^{15}$ The INTERCEPT variable partly captures the differences in future expected earnings of graduates that may systematically vary across majors. They are not, however, statistically significant, suggesting that differences in future earnings are partly measured by some of our quality variables retained in our estimate of the student's expected earnings variable. That last variable, XINCS, is positive and highly statistically significant. This result strongly supports the hypothesis that students choose the major with the

${ }^{15}$ The p-values rejecting the null hypothesis are, following the same order as in the text, $0 \%, 0 \%, 0 \%$ and $1 \%$. 
highest expected earnings. With a p-value for XINCS at 0\%, it clearly establishes that the use of the person specific measures of earnings and the probability of success enhances the predictive power of a regression model using simple average earnings by field. ${ }^{16}$ Breaking down the direct weighted aggregate elasticities of the variable XINCS by major, we obtain respectively a value of 5.94 for the business students, 4.68 for the liberals arts students, 5.63 for the science students and 5.55 for the students enrolled in education ${ }^{17}$.

These elasticities are substantial. We can also establish that at the mean values the elasticity of choosing a particular major with respect to the success variable is smaller than the elasticity with respect to the earnings of graduates. Since we suggested earlier that talented students will mainly react to the earning of graduates variable, then clearly to attract talented students to education, one has to raise the earnings of education graduates.

In Table 7, we report the results of the mixed model applied to the full sample and to some stratified subsamples. Only the estimates for the college student expected earnings variable, XINCS, are presented, with the complete results available from the authors. To compare with specifications used in earlier studies, we also present in Table 7 the results for the probability of success variable, SUCCESS, and the earnings of graduates variable, XEARNG, obtained from separate mixed models.

[Insert Table 7 about here]

The estimations of the mixed model by gender indicate that the statistically significant impact of the expected earnings variable is twice as great for men than for women. This result reflects the willingness of women to go into nontraditional careers. An alternative explanation is that women drop out for reasons related to nonacademic problems. Therefore, the probability of success is less important to them in selecting a major (see Siegfried, 1992). In the narrow specifications, the probability of success variable, SUCCESS, has a positive and statistically significant impact on the choice of major for men, while the coefficient of the earnings of graduates variable, XEARNG is insignificant.

\footnotetext{
${ }^{16}$ Note that a regression model using average earnings by field corresponds with our model assuming a different constant by major without introducing the person-specific measures of expected earnings.

${ }^{17}$ Computations are based on the work of Hensher and Johnson (1981).
} 
In contrast, SUCCESS for women is insignificant but XEARNG has a positive and significant influence. These results appear to support our interpretation of the results from the general specification.

When we stratify by race, the positive and statistically significant impact of XINCS is larger for the nonwhite population than for the white group. If preferences are important in choosing a major, they seem to play a greater role for whites. Here the narrow specifications produce results that are difficult to interpret with no significant variables for the nonwhite sample.

Stratification of the sample by socioeconomic background yields a significant and positive influence of XINCS with, however, no important differences between the groups. When defined separately, SUCCESS is a significant decision factor in choosing a major for the three socioeconomic groups, but not XEARNG. These results are also observed when the narrow specifications are applied to the full sample.

The narrow specifications are not nested in the expected earning variable complete specification and cannot be easily compared. However, in equation (2), we showed that for SUCCESS or XEARNG to be a correct specification for the model of choice of college majors, we have to assume a constant earnings stream across majors or a constant probability of success across majors. These two assumptions were not empirically supported by the results of Tables 4 and 5 .

\section{CONCLUSION}

Elements of equal opportunity and representativity, shortages or surpluses in occupations are important and complex issues related to educational choice. There are many elements entering the choice of concentration of college students. Preferences, information and the family socioeconomic background can all play an important role. In some cases, there can be elements of inequality in educational choice based on gender, race or wealth status of the student. Choosing a concentration is a decision under uncertainty. One major element of that uncertainty concerns the expected earnings with the concentration chosen. Here, in contrast to previous studies, we distinguished three parts to expected earnings : the perceived probability of success or perceived ability and effort needed to complete with success the concentration chosen, the (expected) earnings after graduation and the earnings alternative if the student fails to complete a college program. This paper has analyzed the extent to which the 
choice of concentration depends on the complete expected earnings variable in that concentration relative to other areas of concentration that could have been chosen.

The results show that the choice of college concentration depends decisively on the expected earnings in a particular concentration. There are, however, differences in the impact of the expected earnings variable by gender and race. Women are less influenced by this variable compared to men and nonwhites more than whites. 


\section{References}

Altonji, J.G., (1993), "The Demand for and Return to Education When Education Outcomes Are Uncertain”, Journal of Labor Economic 11, 48-83.

Berger, M.C. (1988a), "Predicted Future Earnings and Choice of College Major", Industrial and Labor Relations Review 41, 418-429.

Berger, M.C. (1988b), "Cohort Size Effects on Earnings : Differences by College Major", Economics of Education Review 7, 375-383.

Betts, J.R. and L.L. McFarland (1995), "The Impact of Labor Conditions on Community College Enrollments", Journal of Human Ressources 30(4), 741-765.

Betts, J.R. (1996), "What Do Students Know about Wages? Evidence from a Survey of Undergraduates" Journal of Human Ressources 31(1), 27-56.

Blakemore, A.E. and S.A. Low (1984), "Sex Differences in Occupational Selection : The Case of College Majors", Review of Economics and Statistics 66, 157-163.

Blau, F.D. and M.A. Ferber (1991), "Career Plans and Expectations of Young Women and Men : The Earnings Gap and Labor Force Participations", The Journal of Human Resources 16, 581-607.

Cannings, K., C. Montmarquette and S. Mahseredjian (1994), "Major Choices : Undergraduate Concentrations and the Probability of Graduation", cahier de recherche no 2394, C.R.D.E., Université de Montréal.

Canes, B.J. and H.S. Rosen (1995), "Following in her Footsteps? Women's Choice of College Majors and Faculty Gender Composition", Industrial and Labor Relations Review 48(3), 482-504.

Duru, M. and A. Mingat (1979), "Comportement des bacheliers : modèle des choix de disciplines", Consommation 3-4, 245-262.

Easterlin, R.A. (1995), "Preferences and Prices in Choice of Career : The Switch to Business, 1972-87", Journal of Economics Behavior and Organization 27, 1-34.

Engle, R., D. Hendry and J.F. Richard (1983), "Exogeneity”, Econometrica 51, 277-304. 
Fiorito, J., and R.C. Dauffenbach (1982), "Market and Nonmarket Influences in Curriculum Choice by College Students", Industrial and Labor Relations Review 36, 88-101.

Hartog, J., G. Pfann and G. Ridder (1989), “(Non-) Graduation and the Earning Function : An Inquiry on Self-Selection”, European Economic Review 33, 1371-1395.

Hensher, D.A. and L.W. Johnson (1981), Applied Discrete-Choice Modelling, London : Croom Helm.

Hoffman, S.D. and G.J. Duncan (1988), "Multinomial and Conditional Logit Discrete-Choice Models in Demography", Demography 25, 415-427.

Kodde, D.A. (1986), "Uncertainty and the Demand for Education", Review of Economics and Statistics 68, 460-467.

McFadden, D.L. (1973), "Conditional Logit Analysis of Quantitative Choice Behavior", in P. Zarembka (ed.), Frontiers in Econometrics, New-York : Academic Press, 105-142.

Manski, C. F. (1993), "Adolescent Econometricians : How Do Youth Infer the Return to Schooling? in "Studies of Supply and Demand in Higher Education, eds. C.T. Clotfelter and M. Rothschild, 43-57. Chicago : The University of Chicago Press.

Maddala, G.S. (1983), Limited-Dependent and Qualitative Variables in Econometrics, Cambridge : Cambridge University Press.

Orazem, P.F. and J.P. Mattila (1986), "Occupational Entry and Uncertainty : Males Leaving High School", Review of Economics and Statistics 68, 265-273.

Paglin, M. and A.M. Rufolo (1990), "Heterogeneous Human Capital, Occupational Choice, and Male-Female Earnings Differences", Journal of Labor Economics 8, 123-144.

Polachek, S.W. (1981), "Occupational Self-Selection : A Human Capital Approach to Sex Difference in Occupational Structure", Review of Economics and Statistics 63, 60-69.

Rogers, A. (1994), "Evolution of Time Preference by Natural Selection", American Economic Review 84, 460-481. 
Rumberger, R.W. and S.L. Thomas (1993), "The Economic Returns to College Major, Quality and Performance : a Multilevel Analysis of Recent Graduates", Economics of Education Review 12, 1-19.

Rupert, P., M. Schweitzer, E. Severaner-Lossin and E. Turner (1996), "Earnings, Education, and Experience", Economic Review 32(4), 2-12.

Siegfried, J.J. (1992), "No Sheepskin Effects for College Women? An Interpretation", manuscript, Vanderbilt University.

Solnick, S.L. (1995), "Changes in Women's College Majors from Entance to Gaduation at Women's and Coeducational Colleges", Industrial and Labor Relations Review 48(3), 505-514.

Zalokar, N. (1988), "Male-Female Differences in Occupational Choice and the Demand for General and Occupation-Specific Human Capital", Economic Inquiry 26, 59-74. 
TABLE 1

The Determinants of College Major Choice :

Major Fields of Study in College

\begin{tabular}{ll}
\hline Constructed Title & \multicolumn{1}{c}{ Description } \\
\hline $\begin{array}{l}\text { Business } \\
\text { (BUSINESS) }\end{array}$ & Business and Management, Business Technology \\
Liberal Arts & $\begin{array}{l}\text { Area Studies, Communications, Fine and Applied Arts, } \\
\text { Foreign Languages, Letters, Psychology, Home }\end{array}$ \\
(LIBARTS) & $\begin{array}{l}\text { Economics, Public Affairs and Services, Social Sciences, } \\
\text { Theology, Interdisciplinary Studies }\end{array}$ \\
& $\begin{array}{l}\text { Agricultural and Natural Resources, Architecture and } \\
\text { Environmental Design, Biological Sciences, Computer } \\
\text { and Information Sciences, Library Science, Mathematics, } \\
\text { (SCIENCE) }\end{array}$ \\
& Military Science, Physical Sciences, Engineering \\
Education & Education \\
(EDUC) &
\end{tabular}


TABLE 2

The Determinants of College Major Choice : Symbol and Variable Definition

\begin{tabular}{|c|c|}
\hline Symbol & Variable Definition \\
\hline \multicolumn{2}{|c|}{$\underline{\text { Personal characteristics }}$} \\
\hline GENDER & 1 if male, 0 if female \\
\hline RACE & 1 if white, 0 if black or hispanic \\
\hline HISPANIC & 1 if hispanic, 0 if black or white \\
\hline BLACK & 1 if black, 0 if hispanic or white \\
\hline ASVABSC1 & ASVAB vocational test scale score - general science \\
\hline ASVABSC2 & ASVAB vocational test scale score - arithmetic reasoning \\
\hline ASVABSC3 & ASVAB vocational test scale score - word knowledge \\
\hline ASVABSC4 & ASVAB vocational test scale score - paragraph comprehension \\
\hline ASVABSC 8 & ASVAB vocational test scale score - mathematics knowledge \\
\hline ASVABS10 & ASVAB vocational test scale score - electronics information \\
\hline \multicolumn{2}{|c|}{$\underline{\text { Socioeconomic factors }}$} \\
\hline FAMINC & total net family income in 1979 (in dollars) \\
\hline MOMEDU & highest grade completed by mother (in years) \\
\hline DADEDU & highest grade completed by father (in years) \\
\hline MOMOCC & $\begin{array}{l}1 \text { if mother worked as a professional, manager or in armed forces in past } \\
\text { calendar year, } 0 \text { otherwise }\end{array}$ \\
\hline DADOCC & $\begin{array}{l}1 \text { if father worked as a professional, manager or in armed forces in past } \\
\text { calendar year, } 0 \text { otherwise }\end{array}$ \\
\hline MAMPROF & 1 if mother professional, 0 otherwise \\
\hline DADPROF & 1 if father professional, 0 otherwise \\
\hline MOMMAN & 1 if mother manager, 0 otherwise \\
\hline DADMAN & 1 if father manager, 0 otherwise \\
\hline NUMSIBLS & number of siblings currently attending or enrolled in school \\
\hline SIBLOEDU & 1 if oldest sibling completed college grade, 0 otherwise \\
\hline FAMILY14 & 1 if mother and father were both present in household at age 14,0 otherwise \\
\hline
\end{tabular}


Table 2 (continued)

\begin{tabular}{ll}
\hline Symbol & Variable Definition \\
\hline Regional characteristics \\
SMSA & 1 if current residence in SMSA, 0 otherwise \\
SOUTH & 1 if region of current residence is South, 0 otherwise \\
URBAN & 1 if current residence urban, 0 rural \\
School factors & \\
FIELD & major field of study at current college \\
EDULOAN & 1 if supported by an educational loan, 0 otherwise \\
PUBLIC12 & 1 if attended grades 1-12 in a public school, 0 otherwise \\
GPA & grade point average (0-4 scale) \\
Others & expected earnings of college students \\
XINCS & estimated probability of success \\
SUCCESS & earnings of graduates \\
XEARNG & earnings alternative \\
XEARNA &
\end{tabular}


TABLE 3

The Determinants of College Major Choice : Mean and Standard Deviation

\begin{tabular}{|c|c|c|c|}
\hline Variable & Total & Male & Female \\
\hline \multicolumn{4}{|c|}{$\underline{\text { Personal characteristics }}$} \\
\hline GENDER & 0.5409 & - & - \\
\hline RACE & 0.8541 & 0.8717 & 0.8333 \\
\hline HISPANIC & 0.0516 & 0.0592 & 0.0426 \\
\hline BLACK & 0.0943 & 0.0691 & 0.1240 \\
\hline ASVABSC1* & $\begin{array}{c}785.5036 \\
(886.6788)\end{array}$ & $\begin{array}{l}1083.1316 \\
(827.3049)\end{array}$ & $\begin{array}{c}434.8101 \\
(825.2226)\end{array}$ \\
\hline ASVABSC2 & $\begin{array}{c}878.3505 \\
(859.6463)\end{array}$ & $\begin{array}{l}1101.3717 \\
(776.1245)\end{array}$ & $\begin{array}{c}615.5659 \\
(880.2185)\end{array}$ \\
\hline ASVABSC3 & $\begin{array}{c}836.4858 \\
(712.8361)\end{array}$ & $\begin{array}{c}929.0263 \\
(656.3658)\end{array}$ & $\begin{array}{c}727.4457 \\
(761.0552)\end{array}$ \\
\hline ASVABSC4 & $\begin{array}{c}658.4751 \\
(615.5204)\end{array}$ & $\begin{array}{c}703.8947 \\
(589.4770)\end{array}$ & $\begin{array}{c}728.1938 \\
(789.4692)\end{array}$ \\
\hline ASVABSC 8 & $\begin{array}{c}917.7171 \\
(799.4230)\end{array}$ & $\begin{array}{l}1078.5625 \\
(773.3431)\end{array}$ & $\begin{array}{c}728.1938 \\
(789.4692)\end{array}$ \\
\hline ASVABSC10 & $\begin{array}{c}620.9235 \\
(873.0622)\end{array}$ & $\begin{array}{l}1031.3289 \\
(738.7942)\end{array}$ & $\begin{array}{c}137.3450 \\
(765.7464)\end{array}$ \\
\hline \multicolumn{4}{|c|}{$\underline{\text { Socioeconomic factors }}$} \\
\hline FAMINC & $\begin{array}{c}26507.3203 \\
(16784.9392)\end{array}$ & $\begin{array}{l}25992.9770 \\
(17350.8996)\end{array}$ & $\begin{array}{l}27195.8488 \\
(16098.8640)\end{array}$ \\
\hline MOMEDU & $\begin{array}{l}12.9342 \\
(2.6042)\end{array}$ & $\begin{array}{l}12.9704 \\
(2.6901)\end{array}$ & $\begin{array}{l}12.8915 \\
(2.5037)\end{array}$ \\
\hline DADEDU & $\begin{array}{l}13.6210 \\
(3.6870)\end{array}$ & $\begin{array}{l}13.5888 \\
(3.7256)\end{array}$ & $\begin{array}{l}13.6589 \\
(3.6479)\end{array}$ \\
\hline MOMOCC & 0.2064 & 0.2105 & 0.2016 \\
\hline DADOCC & 0.4964 & 0.5296 & 0.4574 \\
\hline MAMPROF & 0.1619 & 0.1612 & 0.1628 \\
\hline
\end{tabular}




\begin{tabular}{|c|c|c|c|}
\hline Variable & Total & Male & Female \\
\hline \multicolumn{4}{|c|}{$\underline{\text { Socioeconomic factors }}$} \\
\hline DADPROF & 0.2384 & 0.2730 & 0.1977 \\
\hline MOMMAN & 0.0445 & 0.0493 & 0.0388 \\
\hline DADMAN & 0.2509 & 0.2533 & 0.2481 \\
\hline NUMSIBLS & $\begin{array}{c}1.6246 \\
(1.4279)\end{array}$ & $\begin{array}{c}1.4770 \\
(1.3786)\end{array}$ & $\begin{array}{c}1.7984 \\
(1.4676)\end{array}$ \\
\hline SIBLOEDU & 0.4822 & 0.4770 & 0.4884 \\
\hline FAMILY14 & 0.8630 & 0.8651 & 0.8605 \\
\hline \multicolumn{4}{|c|}{$\underline{\text { Regional characteristics }}$} \\
\hline SMSA & 0.7367 & 0.7401 & 0.7326 \\
\hline SOUTH & 0.2954 & 0.2796 & 0.3140 \\
\hline URBAN & 0.8310 & 0.8454 & 0.8140 \\
\hline \multicolumn{4}{|l|}{$\underline{\text { School factors }}$} \\
\hline EDULOAN & 0.2384 & 0.2401 & 0.2364 \\
\hline PUBLIC12 & 0.8559 & 0.8520 & 0.8605 \\
\hline GPA & $\begin{array}{c}2.0178 \\
(1.4204)\end{array}$ & $\begin{array}{c}2.3882 \\
(1.4004)\end{array}$ & $\begin{array}{c}1.5814 \\
(1.3185)\end{array}$ \\
\hline \multicolumn{4}{|l|}{$\underline{\text { Major choice }}$} \\
\hline BUSINESS & 0.2669 & 0.2664 & 0.2674 \\
\hline LIBARTS & 0.3363 & 0.2928 & 0.3876 \\
\hline SCIENCE & 0.2794 & 0.3684 & 0.1744 \\
\hline EDUCATION & 0.1174 & 0.0724 & 0.1705 \\
\hline Sample size & 562 & 304 & 258 \\
\hline
\end{tabular}

* ASVAB scores have three implied decimals. 
TABLE 4

Means of Observed Variables and the Predicted Probability of Success

\begin{tabular}{lcccccccccccc}
\hline & \multirow{2}{*}{ Observed } & \multicolumn{10}{c}{ Perceived } \\
\cline { 3 - 12 } & & & \multicolumn{1}{c}{ Business } & \multicolumn{1}{c}{ Liberal Arts } & \multicolumn{1}{c}{ Science } & \multicolumn{2}{c}{ Education } \\
\hline & M & $\mathrm{F}$ & $\mathrm{M}$ & $\mathrm{F}$ & $\mathrm{M}$ & $\mathrm{F}$ & $\mathrm{M}$ & $\mathrm{F}$ & $\mathrm{M}$ & $\mathrm{F}$ \\
\hline \multirow{2}{*}{ Business } & 0.52 & 0.38 & 0.52 & 0.37 & 0.45 & 0.47 & 0.44 & 0.21 & 0.48 & 0.63 \\
Liberal arts & 0.42 & 0.5 & 0.45 & 0.38 & 0.42 & 0.5 & 0.41 & 0.24 & 0.51 & 0.76 \\
Science & 0.57 & 0.36 & 0.6 & 0.49 & 0.45 & 0.54 & 0.57 & 0.35 & 0.52 & 0.78 \\
Education & 0.45 & 0.64 & 0.35 & 0.31 & 0.35 & 0.43 & 0.31 & 0.19 & 0.46 & 0.64 \\
\hline
\end{tabular}

TABLE 5

Means of Predicted Earnings of Graduates

\begin{tabular}{lccccccccc}
\hline & \multicolumn{2}{c}{ Business } & \multicolumn{2}{c}{ Liberal Arts } & \multicolumn{2}{c}{ Science } & \multicolumn{2}{c}{ Education } \\
\cline { 2 - 10 } & $\mathrm{M}$ & $\mathrm{F}$ & $\mathrm{M}$ & $\mathrm{F}$ & $\mathrm{M}$ & $\mathrm{F}$ & $\mathrm{M}$ & $\mathrm{F}$ \\
\hline \multirow{2}{*}{ Business } & 21,298 & 18,690 & 18,545 & 15,824 & 21,960 & 18,525 & 16,866 & 13,680 \\
Liberal arts & 21,369 & 19,106 & 18,619 & 16,192 & 22,040 & 18,949 & 16,902 & 13,987 \\
Science & 21,301 & 19,634 & 18,565 & 16,623 & 21,975 & 19,469 & 16,852 & 14,358 \\
Education & 21,163 & 18,677 & 18,449 & 15,829 & 21,838 & 18,534 & 16,738 & 13,680 \\
\hline
\end{tabular}


TABLE 6

The Determinants of College Major Choice : Mixed Model Analysis of the Full Sample

\begin{tabular}{|c|c|c|c|}
\hline Variable & Comparison & $\begin{array}{c}\text { Coefficient } \\
\text { Estimate } \\
\end{array}$ & Standard Error \\
\hline \multicolumn{4}{|c|}{$\underline{\text { Personal characteristics }}$} \\
\hline \multirow[t]{3}{*}{ GENDER } & $1 / 4$ & $0.5679^{c}$ & 0.3339 \\
\hline & $2 / 4$ & $0.6600^{\mathrm{a}}$ & 0.3166 \\
\hline & $3 / 4$ & $0.8098^{\mathrm{a}}$ & 0.3561 \\
\hline \multirow[t]{3}{*}{ RACE } & $1 / 4$ & 0.1044 & 0.4846 \\
\hline & $2 / 4$ & -0.2239 & 0.4587 \\
\hline & $3 / 4$ & -0.3592 & 0.4848 \\
\hline \multicolumn{4}{|c|}{$\underline{\text { Socioeconomic factors }}$} \\
\hline \multirow[t]{3}{*}{ FAMINC } & $1 / 4$ & 0.00001006 & 0.00001158 \\
\hline & $2 / 4$ & 0.00001283 & 0.00001103 \\
\hline & $3 / 4$ & 0.00000743 & 0.00001148 \\
\hline \multirow[t]{3}{*}{ MOMEDU } & $1 / 4$ & -0.04022 & 0.08623 \\
\hline & $2 / 4$ & 0.01195 & 0.08489 \\
\hline & $3 / 4$ & -0.005802 & 0.08690 \\
\hline \multirow[t]{3}{*}{ DADEDU } & $1 / 4$ & -0.02343 & 0.06411 \\
\hline & $2 / 4$ & 0.04780 & 0.06203 \\
\hline & $3 / 4$ & 0.01983 & 0.06464 \\
\hline \multirow[t]{3}{*}{ MOMOCC } & $1 / 4$ & 0.1386 & 0.4645 \\
\hline & $2 / 4$ & 0.1847 & 0.4350 \\
\hline & $3 / 4$ & 0.3235 & 0.4543 \\
\hline \multirow[t]{3}{*}{ DADOCC } & $1 / 4$ & -0.2580 & 0.3910 \\
\hline & $2 / 4$ & -0.03474 & 0.3715 \\
\hline & $3 / 4$ & -0.3188 & 0.3899 \\
\hline \multirow[t]{3}{*}{ NUMSIBLS } & $1 / 4$ & 0.1416 & 0.1195 \\
\hline & $2 / 4$ & 0.05898 & 0.1159 \\
\hline & $3 / 4$ & $0.2082^{c}$ & 0.1198 \\
\hline \multirow[t]{3}{*}{ SIBLOEDU } & $1 / 4$ & 0.5500 & 0.3349 \\
\hline & $2 / 4$ & 0.02062 & 0.3213 \\
\hline & $3 / 4$ & 0.1882 & 0.3351 \\
\hline
\end{tabular}




\section{TABLE 6 (continued)}

\begin{tabular}{|c|c|c|c|}
\hline Variable & Comparison & $\begin{array}{c}\text { Coefficient } \\
\text { Estimate }\end{array}$ & Standard Error \\
\hline FAMILY14 & $\begin{array}{l}1 / 4 \\
2 / 4 \\
3 / 4\end{array}$ & $\begin{array}{l}-0.3677 \\
-0.8289^{c} \\
-0.4849\end{array}$ & $\begin{array}{l}0.5126 \\
0.4744 \\
0.5094\end{array}$ \\
\hline \multicolumn{4}{|c|}{$\underline{\text { Regional characteristics }}$} \\
\hline SMSA & $\begin{array}{l}1 / 4 \\
2 / 4 \\
3 / 4\end{array}$ & $\begin{array}{c}0.3767 \\
0.7674^{\mathrm{a}} \\
-0.09287\end{array}$ & $\begin{array}{l}0.3576 \\
0.3510 \\
0.3592\end{array}$ \\
\hline SOUTH & $\begin{array}{l}1 / 4 \\
2 / 4 \\
3 / 4\end{array}$ & $\begin{array}{r}0.3733 \\
-0.3334 \\
-0.1732\end{array}$ & $\begin{array}{l}0.3542 \\
0.3434 \\
0.3559\end{array}$ \\
\hline \multicolumn{4}{|l|}{$\underline{\text { School factors }}$} \\
\hline EDULOAN & $\begin{array}{l}1 / 4 \\
2 / 4 \\
3 / 4\end{array}$ & $\begin{array}{l}-0.8297^{\mathrm{a}} \\
-0.3937 \\
-0.9582^{\mathrm{a}}\end{array}$ & $\begin{array}{l}0.3716 \\
0.3456 \\
0.3749\end{array}$ \\
\hline PUBLIC12 & $\begin{array}{l}1 / 4 \\
2 / 4 \\
3 / 4\end{array}$ & $\begin{array}{c}-0.1865 \\
0.07949 \\
0.05801\end{array}$ & $\begin{array}{l}0.4853 \\
0.4697 \\
0.4971\end{array}$ \\
\hline XINCS & & $0.0005262^{\mathrm{a}}$ & 0.0000718 \\
\hline INTERCEPT & $\begin{array}{l}1 / 4 \\
2 / 4 \\
3 / 4\end{array}$ & $\begin{array}{c}0.08358 \\
-0.2568 \\
0.1069\end{array}$ & $\begin{array}{l}1.1992 \\
1.1748 \\
1.2315\end{array}$ \\
\hline \multicolumn{4}{|c|}{$\underline{\text { Other statistics }}$} \\
\hline \multicolumn{2}{|l|}{ Sample size } & 562 & \\
\hline \multicolumn{2}{|c|}{ Log of the likelihood function } & -677.5167 & \\
\hline \multicolumn{2}{|c|}{$\begin{array}{l}\text { Chi-square statistic of the model } \\
\text { (degrees of freedom) }\end{array}$} & $\begin{array}{l}136.3081 \\
(43)\end{array}$ & \\
\hline
\end{tabular}

Notes : a Significantly different from zero at the 1 percent level.

b Significantly different from zero at the 5 percent level.

c Significantly different from zero at the 10 percent level. 
TABLE 7

Estimates of Mixed Model Stratified Subsamples

\begin{tabular}{|c|c|c|c|c|}
\hline Sample & XINCS & SUCCESS & XEARNG & $\begin{array}{c}\text { Number of } \\
\text { Observations }\end{array}$ \\
\hline Full & $\begin{array}{c}0.0005262^{\mathrm{a}} \\
(0.00007183)\end{array}$ & $\begin{array}{c}2.3948^{\mathrm{a}} \\
(0.4953)\end{array}$ & $\begin{array}{c}0.0006220 \\
(0.0004062)\end{array}$ & 562 \\
\hline \multicolumn{5}{|l|}{ Stratified } \\
\hline \multicolumn{5}{|l|}{ By gender } \\
\hline Male & $\begin{array}{c}0.0007448^{\mathrm{a}} \\
(0.0001084)\end{array}$ & $\begin{array}{l}4.0238^{\mathrm{a}} \\
(0.7730)\end{array}$ & $\begin{array}{l}0.0005811 \\
(0.001106)\end{array}$ & 304 \\
\hline Female & $\begin{array}{c}0.0003740^{\mathrm{a}} \\
(0.0001048)\end{array}$ & $\begin{array}{c}0.9005 \\
(0.6953)\end{array}$ & $\begin{array}{c}0.001484^{\mathrm{a}} \\
(0.0005313)\end{array}$ & 258 \\
\hline \multicolumn{5}{|l|}{ By race } \\
\hline White & $\begin{array}{c}0.0005251^{\mathrm{a}} \\
(0.00007879)\end{array}$ & $\begin{array}{r}2.4249^{\mathrm{a}} \\
(0.5472)\end{array}$ & $\begin{array}{c}0.0008842^{\mathrm{b}} \\
(0.0004474)\end{array}$ & 480 \\
\hline Nonwhite & $\begin{array}{c}0.0008331^{\mathrm{a}} \\
(0.0002331)\end{array}$ & $\begin{array}{l}3.1574^{c} \\
(1.6206)\end{array}$ & $\begin{array}{c}0.001169 \\
(0.001353)\end{array}$ & 82 \\
\hline \multicolumn{5}{|c|}{ By socioeconomic background } \\
\hline Low $^{1}$ & $\begin{array}{c}0.0007285^{\mathrm{a}} \\
(0.0001605)\end{array}$ & $\begin{array}{l}3.4733^{\mathrm{a}} \\
(1.0577)\end{array}$ & $\begin{array}{c}0.0004598 \\
(0.0009398)\end{array}$ & 144 \\
\hline Middle $^{2}$ & $\begin{array}{c}0.0004806^{\mathrm{a}} \\
(0.00009873)\end{array}$ & $\begin{array}{c}1.7922^{\mathrm{a}} \\
(0.7048)\end{array}$ & $\begin{array}{c}0.0009646 \\
(0.0005913)\end{array}$ & 287 \\
\hline $\operatorname{High}^{3}$ & $\begin{array}{c}0.0007331^{\mathrm{a}} \\
(0.0001961)\end{array}$ & $\begin{array}{r}3.6044^{\mathrm{a}} \\
(1.2557) \\
\end{array}$ & $\begin{array}{c}0.001666 \\
(0.001061) \\
\end{array}$ & 131 \\
\hline
\end{tabular}

Notes : ( ) : Standard error.

1 Based on family income $\leq \$ 14,990$.

2 Based on family income between $\$ 14,990$ and $\$ 35,280$.

3 Based on family income $\geq \$ 35,280$.

a Significantly different from zero at the 1 percent level.

b Significantly different from zero at the 5 percent level.

c Significantly different from zero at the 10 percent level. 


\section{Liste des publications au CIRANO .}

\section{Cahiers CIRANO / CIRANO Papers (ISSN 1198-8169)}

96c-1 Peut-on créer des emplois en réglementant le temps de travail ? / Robert Lacroix

95c-2 Anomalies de marché et sélection des titres au Canada / Richard Guay, Jean-François L'Her et Jean-Marc Suret

95c-1 La réglementation incitative / Marcel Boyer

94c-3 L'importance relative des gouvernements : causes, conséquences et organisations alternative / Claude Montmarquette

94c-2 Commercial Bankruptcy and Financial Reorganization in Canada / Jocelyn Martel

94c-1 Faire ou faire faire : La perspective de l'économie des organisations / Michel Patry

Série Scientifique / Scientific Series (ISSN 1198-8177)

97s-38 How Do young People Choose College Majors? / Claude Montmarquette, Kathy Cannings et Sophie Mahseredjian

97s-37 A General Equilibrium Analysis of the Evolution of the Canadian Service Productivity / Pierre Mohnen et Thijs ten Raa

97s-36 Moving towards the Virtual Economy: A Major Paradigm Shift / Louis A. Lefebvre et Élisabeth Lefebvre

97s-35 Seasonal Time Series and Autocorrelation Function Estimation / Hahn Shik Lee, Eric Ghysels et William R. Bell

97s-34 Do Canadian Firms Respond to Fiscal Incentives to Research and Development? / Marcel Dagenais, Pierre Mohnen et Pierre Therrien

97s-33 A Semi-Parametric Factor Model of Interest Rates and Tests of the Affine Term Structure / Eric Ghysels et Serena Ng

97s-32 Emerging Environmental Problems, Irreversible Remedies, and Myopia in a Two Country Setup / Marcel Boyer, Pierre Lasserre et Michel Moreaux

97s-31 On the Elasticity of Effort for Piece Rates: Evidence from the British Columbia Tree-Planting Industry / Harry J. Paarsch et Bruce S. Shearer

97s-30 Taxation or Regulation: Looking for a Good Anti-Smoking Policy / Paul Leclair et Paul Lanoie

97s-29 Optimal Trading Mechanisms with Ex Ante Unidentified Traders / Hu Lu et Jacques Robert

97s-28 Are Underground Workers More Likely To Be Underground Consumers? / Bernard Fortin, Guy Lacroix et Claude Montmarquette

\footnotetext{
* Vous pouvez consulter la liste complète des publications du CIRANO et les publications elles-mêmes sur notre site World Wide Web à l'adresse suivante :

http://www.cirano.umontreal.ca/publication/page1.html
} 